\title{
ALBANIA IN THE WORLD TRADE ORGANIZATION: COMMITMENTS AND CHALLENGES
}

\author{
Megi Melani \\ PhD Candidate, External Lecturer at "Aleksandër Xhuvani" University, ALBANIA, \\ megi.melani@gmail.com
}

\begin{abstract}
Albania joined the World Trade Organization (WTO) on September 8, 2000, aiming at a more active participation of the country in the multilateral trade system; the expansion of the internal market and creation of a more attractive environment to foreign investment; the commitment to good governance through the rule of law ensuring the adherence to the rules of the game that cannot change according to wishes; establishing the foundations for the achievement of economic and commercial standards with a view to joining the European Union as well as a fair and more favorable treatment of domestic and foreign commercial operators. This paper aims to primarily describe the Albanian commitments under the WTO which consist in three main areas: goods trade, service trade, intellectual property as well as two dimensions: the alignment of the Albanian legislation with that of the WTO and the Albanian concrete offer in each of the above mentioned areas. However, in order to create a more comprehensive view, the paper also describes the transparency commitments related to multilateral agreements. WTO represents a multilateral trading system based on principles and rules expressed in a full legal package, according to which each member state enjoys its rights and owes obligations. In fulfillment of the commitments stemming from the membership of the WTO, the Albanian government has reduced the customs duty rates which has lead to increasing trade exchange with the WTO member countries. In this context, honoring the commitments is a matter of particular significance to Albania.
\end{abstract}

Keywords: World Trade Organization, Agreement, Commitments, Trade System, Albania.

\section{INTRODUCTION}

World Trade Organization (WTO) is an international organization that expresses the commitment of many countries to respect clear rules of the game regarding international trade, and determines the rules that the Member States should follow in their trade with other countries. These rules are stated in the agreements negotiated and signed by the participating countries. They are in themselves contracts that oblige the member states to adhere to the policy limits agreed upon. WTO does not tell the states what to do, or how to develop their commercial policies. It provides the framework of developing trade in a correct, free and fair way. In addition, it provides positive examples of international trade development in the global trading system. Therefore, the countries that want to develop a free and fair trade system, seek to become part of this organization. (VanGrasstek, 2013, p.12)

The foundation of World Trade Organization has brought a change in the policy course of the global trading system, especially through placing great importance on the promotion of economic activities. Albania joined 
the WTO in $2000,{ }^{1}$ following a negotiation process with WTO member countries. The negotiation processes prior to membership as well as the process of implementing the commitments to the WTO, are accompanied by reforms and attempts to raise standards ${ }^{2}$, which are necessary to adapt to the current situation of global trade. The Initiatives taken by the Albanian government to satisfy commitments under the WTO, are becoming increasingly important not only because they affect the economic development of the country, but also because they constitute the conditions for European and regional integration.

In terms of methodology, this paper will focus on a preliminary hypothesis based on which we might infer that Albania's membership of the World Trade Organization has brought new commitments to the Albanian reality. For this purpose, we have presented different arguments based on primary sources we have exploited, particularly the review of the documentation on the relations with the WTO and the economic integration, by the Albanian Department at the Ministry of Economy, year 2003-2010. Another significant part of the sources used here are the books and articles that WTO has recently published. We have also consulted the Protocol of Accession accompanied by the Report of the Working Group of Albania, which contains the schedule of commitments for immediate and gradual liberalization of tariffs on goods and services, the implementation of standards for intellectual property protection as well as the reforms related to the privatization and a series of other measures concerning the institutionalization of the market economy in Albania. $^{3}$

The negotiation process before and after membership, also as the fulfilling the commitments to WTO, have been followed by necessary reforms and improvement of standards, in order to adapt to the today's global trade needs. All the Albanian post-communist governments, despite their political view, had as their priority the integration and membership in WTO. The logic of WTO by all means the logic of the further liberalisation. Initiatives taken from the Albanian Government, to fulfill the commitments to WTO, are becomming more and more inportant, not only because they are affecting the economical grouth of the country, but also because they are conditions to the European integration and further.

Albania, much like many other countries, became a member of WTO with full rights and obligations, following the submission and ratification of the Protocol of Accession under Article XII of the WTO Agreement. ${ }^{4}$

Albania is committed to liberalize its tariff regime by applying a tariff reduction process, in order to implement all the commitments arising from the agreements on Technical Barriers to Trade (TBT) and Sanitary and Phytosanitary Standards (SPS). Also, the Albanian Customs Code states that customs valuation is made in accordance with WTO requirements.

After accession to the WTO in 2000, compliance with all WTO rules was considered the main trade policy driving force. Currently, trade policy changes are driven mainly by compliance to EU law. The Albanian authorities consider this to be a complement to the changes already implemented for compliance with WTO rules, which remain the base platform of minimum requirements for Albania's trade policy regime.

\section{ALBANIA'S COMMITMENTS TO WORLD TRADE ORGANIZATION}

Albania is highly committed to conducting trade profound reforms aiming at restructuring the economy and integrating the country internationally. These reforms are rigorously implemented and produce satisfactory results, especially in terms of goods trade liberalization in the Balkan region, with the aim of creating a free trade area between the neighboring countries that consequently guarantees a successful integration of the Albanian goods into the European market. ${ }^{5}$

The situation in the field of services could be described as slightly different. It is less developed due to lack of experience and the specific characteristics of trade in services. However, attempts are constantly made to

\footnotetext{
1 Since then, Albania has continued to actively promote economic, legal, and institutional reform, and this has resulted in an open trade and investment regime, characterized by low tariffs and few non-tariff barriers to trade. A considerable effort has also been made on the administrative side to facilitate trade and investment flows.

${ }^{2}$ Ministry of Economy. (25/11/2007). Document submitted to the Albanian Department on the relations with the WTO and economic integration. The position of Albania to the WTO negotiations.

${ }^{3}$ Official Bulletin of the Republic of Albania.(2004).Extra, p.5-58.

4 The basic laws through which Albania approved and formally undertook the obligations of WTO Membership, are Law No. 8,648 of 27 July 2000, On ratification of the Protocol of the accession of the Republic of Albania to the Marrakech Agreement Establishing the World Trade Organization, and Law No. 8,649 of 27 July 2000, On ratification of the Agreements of the Results of the Uruguay Round of Multilateral Trade Negotiations.

${ }^{5}$ Ministry of Economy. (08.09.2004). Document submitted to the Albanian Department on the relations with the WTO and economic integration. Reforming policies of liberalization in the framework of WTO.
} 
deepen the liberalization process in this field as well, primarily through regional integration policies, in collaboration with international organizations.

Albania has taken on commitments on two levels: firstly, the commitment to respect all multilateral agreements within the framework of WTO, and secondly, the allocation of concrete concessions on goods and services markets.

\subsection{Trade in Goods}

Since its membership of the WTO, Albania is committed to approximate its legislation to that of WTO. The document that contains the basic principles of trade in goods is the General Agreement on Trade and Tariffs (GATT). These principles are represented by four basic rules and a number of other general rules. General Agreement on Trade and Tariffs is interpreted and supplemented, thus becoming operational, by a series of other agreements related to the GATT. Each member of the WTO must adjust its legislation under these agreements. Official promises to bring domestic legislation in line with WTO agreements are converted into concrete monitored commitments. Since its membership, Albania has been committed that all laws and regulations, as well as fees, charges and taxes on trade in goods are in conformity with the WTO agreements. The implementation also conforms to WTO rules. Before membership, Albania made several amendments to the legislation on sanitary and phytosanitary measures, technical regulations on trade, import licensing procedures, so that its legislation complies with the rules of WTO. (Skreli, 2005, p.21)

Albania is committed to implement all WTO agreements, including sanitary and phytosanitary measures and technical regulations in trade, without any transition period. In addition, Albania has not applied antidumping, counterbalancing and safety measures without primarily completing the relevant legislation and bringing it in line with the WTO.

The offer in the goods market is characterized by a simple tariff system. The maximum level of tariff binding is $20 \% .^{6}$

The idea of reducing to zero the tariffs of products is, as a rule related to: multilateral agreements or statements, the Ministerial Declaration on Trade in Information Technology Products, which states that tariffs on these products should become zero at a constant reduction pace, according to the membership obligations under the Multilateral Civil Aviation Agreement. It is also related to concessions on other member countries of the WTO for products embodying less capital gain, in response to demand for concessions by these countries and the reduction of tariffs on raw materials to encourage domestic production.

Agricultural offer of goods includes a lack of active programs of support through subsidies. The de minims value is $5 \%$, while the aggregate measure of support (AMS) is zero.

\subsection{Trade in Services}

The General Agreement on Trade in Services (GATS) ${ }^{7}$ contains the basic principles of trade in services, such as the principle of most favored nation with some exceptions, market concessions, the attainment of the status of national treatment, the demand for transparency. GATS is interpreted and supplemented, thus becoming operational, by a series of other agreements related to it, such as the movement of persons, financial services, telecommunications, air transport and shipping.

Albania is, in principle, awarded the status of the most favored nation for almost all types of services, with the exception of some transport and audio-visual services, on which a preferential treatment is applied. ${ }^{8}$ Preferential treatment is conditioned by bilateral or multilateral agreements; with reference to Albania, access to markets can be regarded as a rule. The acquisition of the national treatment status may be also considered a rule. Restrictions on national treatment derive from restrictions on non-agricultural land market, restrictions on professional hospital medical services, on legal services, insurance service restrictions and restrictions on cinema and theatre services.

\footnotetext{
${ }^{6}$ https://www.wto.org/ WT/ALB/51/Add.1:Goods Schedule

7 In its GATS schedule, Albania has made commitments in 108 of 155 services sectors. In its horizontal commitments, the main limitations are in real estate and entry and temporary stay of foreign natural persons (intra-corporate transferees, service sellers, and persons responsible for setting up a commercial presence). Albania maintains MFN exemptions under Article II of the GATS in road transport services (passengers and freight), sale and marketing of air transport services and computer reservation systems (CRS), audio-visual services (production and distribution of: audiovisual works through broadcasting or other forms of transmission to the public, and television programmes and cinematographic works).

8 Ministry of Economy. (2005).Document submitted to the Albanian Department on the relations with the WTO and economic integration. On specific commitments on trade in services in the WTO. Prot. No. 1103
} 
The supply of services essentially covers modes 1,2, and 4 . The Stabilization and Association Council will within five years from the entry into force of the Agreement take the measures necessary to implement progressively this liberalization of trade in services between the Parties. ${ }^{9}$

Albania has no GATS commitments in audiovisual services although it has full commitments in postal services related to parcels, courier services, and some telecommunication services except mode 4 limitations on market access. The attached reference paper on regulatory principles is incorporated as additional commitments by Albania. (World Trade Organization, 2011, p.13)

Under its GATS schedule, Albania has made full commitments in construction and related engineering services except mode 4 limitations on market access. Apart from mode 3 limitations on national treatment for some sub-sectors of commission agent's services, wholesale trade services, and retailing services, and mode 4 limitations on market access, Albania also has full commitments in distribution services.

Albania has commitments in the four main educational services (i.e., primary, secondary, higher, and adult education). For primary and secondary education, it has no market access limitations in modes 2-3. For higher secondary, higher education, and adult education, it has no market access limitations in modes 1-3. Albania has no limitations on national treatment across the four modes in all education services it has made commitments in. (World Trade organization, 2011, p.14)

Albania in its GATS schedule, has full commitments in environmental services except mode 4 limitations on market access. (World Trade Organization, 2011, p.15-17)

In its GATS schedule, Albania has scheduled some limitations on national treatment in mode 3 for some insurance and insurance-related services (i.e., life and non-life insurance services, marine, aviation and transport services, reinsurance and retrocession) that commercial presence is restricted to those companies that have exercised insurance activities in the home country for at least five years and the general representative of such companies must reside in Albania. In banking and other financial services, Albania has no limitations on national treatment across the four modes, although certain sub-sectors are unbound for mode 1 on market access. In mode 2 on market access, Albania has scheduled limitations (up to 2010) for certain banking and other financial services that the Bank.(World Trade Organization, 2011, p.18)

In its GATS schedule, Albania has made commitments in hospital and other human health services with no limitations except that for commercial presence, licensing shall be in cooperation with an Albanian professional whether this professional is a partner or an employee in the foreign company. Albania has not made any commitments in social services. Mode 4 is unbound except as indicated in the horizontal section.

In Albania's GATS schedule, it has fully committed in hotels and restaurants services, travel agencies and tour operators services, tourist guide services, news agency services, library services, and sporting and other recreational services except mode 4 limitations on market access. For cinema theatre operation services, commercial presence is not limited except it is unbound for access to subsidies. ${ }^{10}$

In its GATS schedule, Albania has fully committed in several transport services except mode 4 limitations on market access. For storage and warehousing services, limitations on commercial presence are not registered. However, in case of occupation of the public domain, public utility concessions or licensing procedures may apply. Internal waterways transport, some of air transport services, space transport, rail transport services, and pipeline transport are not scheduled.

In its GATS schedule, Albania has made extensive commitments in business services and liberalized modes 1-3 for the majority of sub-sectors. Exceptions include a reservation taken for: legal services that only Albanian citizens attorneys at law and notaries who reside in Albania have the right to provide the services; and medical and dental services, and services provided bymidwives nurses, physiotherapists and paramedical personnel that licensing is done only in cooperation with an Albanian professional whether this professional is a partner or an employee in the foreign company. There are no mode 4 limitations on national treatment across all the sub-sectors committed except legal services. Albania has no commitments research and development services; real estate services; rental/leasing services without operators relating to ships, aircraft, other transport equipment, and other machinery and equipment; services incidental to energy distribution; placement and supply services of personnel; and investigation and security.(Skreli, 2005, p.23)

Albania authorizes as from the entry into force of the Agreement the acquisition of real estate in Albania by EU nationals, except for its scheduled limitations in the GATS. Within seven years from the entry into force of

\footnotetext{
${ }_{9}^{9}$ https://www.wto.org/ WT/ALB/51:Report on the working Parties

$10 \mathrm{https}: / /$ www.wto.org/WT//ALB/51/Add.2:Services Schedule
} 
the Agreement (i.e., by 31 March 2016), Albania shall progressively adjust its legislation to offer national treatment to EU nationals in this regard.

\subsection{Intellectual Property}

When it became a member of WTO, Albania was in compliance with the Agreement on Intellectual Property. ${ }^{11}$ It has been committed to implement the Agreement on Intellectual Property without any transition period.

One of the six legal blocks of WTO is that related to the obligation to make measures, policies and laws affecting foreign trade transparent. First, governments should inform WTO member countries on measures, specific policies or laws through regular notifications, and secondly, WTO undertakes regular reviews of member countries' trade policies, or what is known as the trade policy reviews.

In this context, Albania is committed to make the notifications required by any agreement that is part of the legal structure of the WTO. (Skreli, 2005, p.24)

WTO members on 6 December 2005 approved changes to the WTO's intellectual property (TRIPS) agreement making permanent a decision on patents and public health originally adopted in 2003 . This will now be formally built into the TRIPS Agreement when two thirds of the WTO's members have accepted the change. They originally set themselves until 1 December 2007 to do this. Regarding multilateral agreements, Albania has undertaken commitments to begin negotiations for membership of the Governmental Procurement Agreement, with the aim of becoming a member in late 2000, and consequently implement various agreements arising from membership of this organization. ${ }^{12}$

As motivation, one of the fundamental contributions of the WTO system's architecture is that it allows for substantial monitoring of changes to the national policies that have an impact on the conditions of foreign market access and hence, the flows of international trade. The WTO architecture has resulted in a system of rules as well as reporting requirements that makes it possible to transmit information concerning how one Member's policy changes are expected to affect the foreign market access interests of exporters in other WTO Member economies. (Cottier \& Manfred, 2011, p.157)

\section{ALBANIA IN THE WORLD TRADE ORGANIZATION, A COUNTRY IN TRANSITION: BENEFITS DERIVING FROM THIS STATUS}

When a country becomes a member of WTO, it acquires a certain status as to the following categories: less developed countries, developing countries, countries in transition, developed countries. For the classification of the least developed countries, the WTO uses the United Nations system. Currently, there are about 48 such countries members of the WTO. However, there is no clear or written definition as to in which group should the other countries be included. Determining whether a country is a developing one is voluntary or based on the principle of self-determining.

The negotiators of the WTO agreements recognized that the system of rules is only as good as its implementation. They decided that the best way to ensure that the rules and other commitments are being respected is to give members themselves the information necessary to undertake collective surveillance by requiring each Member to notify specific actions or changes in policies or sometimes the absence of any action or change. (Gallagher, 2005, p.23)

Countries that had a centralized economy in the past and are currently in the early stages of transition to a free market economy and democracy are treated as countries in transition. Albania is part of this group. The countries that do not belong to the above classifications are classified as developed countries. Countries in transition, including Albania, have flexibility in accepting binding commitments in trade negotiations as in the

\footnotetext{
${ }^{11}$ The Agreement on Trade-Related Aspects of Intellectual Property Rights (TRIPS) is an international agreement administered by the World Trade Organization (WTO) that sets down minimum standards for many forms of intellectual property (IP) regulation as applied to nationals of other WTO Members. ${ }^{[2]}$ It was negotiated at the end of the Uruguay Round of the General Agreement on Tariffs and Trade (GATT) in 1994.The TRIPS agreement introduced intellectual property law into the international trading system for the first time and remains the most comprehensive international agreement on intellectual property to date. In 2001, developing countries, concerned that developed countries were insisting on an overly narrow reading of TRIPS, initiated a round of talks that resulted in the Doha Declaration. The Doha declaration is a WTO statement that clarifies the scope of TRIPS, stating for example that TRIPS can and should be interpreted in light of the goal "to promote access to medicines for all.

12 WTO online information: https://www.wto.org/WT/ALB/40/Rev.2;Changes in Albanian Legislation for Complying with WTO agreements
} 
case of trade in services, with respect to which the agreement gives the states flexibility to liberalize fewer sectors or types of transactions; advantages in providing longer-lasting protection for the development of new industries and domestic restrictive measures in case of difficulties such as the balance of payments; transitional period to accept commitments. Transitional periods range from 5 to 10 years and serve to enable countries to prepare for the acceptance of these commitments such as the Agreement on Customs Valuation which is to be prepared by a member state within a period of 5 years; the exemption from some specific binding commitments.

Being under a WTO classification category enables countries to cooperate closely with each other in case they want to make important proposals for changes. So, in Cancun, Albania joined the countries of Central and Eastern Europe to achieve its objective of increasing the level of de minims from $5 \%$ to $10 \%$ for subsidies under the Agriculture Agreement, which can also be applied to many other fields. Although the absence of agreement on modalities for moving forward is a disappointment, in one fundamental aspect Cancun can be seen as positive: Attempts by major trading powers to dilute the Doha mandate on agriculture did not prosper, and the voice of the developing world was taken into consideration. (Amorim, 2003, p.1)

Albania highlighted that full compliance with WTO rules guided its trade agenda, and that the foundation of Albania's trade and economic reforms had been the main WTO principles of transparency, predictability, and accountability.

\section{WORLD TRADE ORGANIZATION: A PRECURSOR TO ALBANIA'S INTEGRATION INTO THE EUROPEAN UNION}

The common European market relies extensively on the principle of non-discrimination of products on grounds of nationality, which is the basic principle of the WTO. On the other hand, both institutions put a special emphasis on respect for the rules of the game in trade. One of the essential differences, certainly not the only one, is that EU standards are much higher than those of the WTO. In this context, when discussing foreign trade, the WTO can be considered as a precondition on the way towards the European Union.

Membership of a country in the WTO, poor or developing, is voluntary. But, it should be noted that Albania's membership in the WTO, besides the economic aspect, had also a significant political impact. The aspiration towards European Union had as its prerequisite the membership of the WTO, in order for Albania to create a liberalized trade regime, to demonstrate that it is able to undertake commitments and implement them. There is a strong connection between Albania's membership in the WTO and the negotiations in the framework of European integration. ${ }^{13}$

It should be mentioned here that failure of some commitments for reducing the tariffs of some products to $0 \%$, resulted in a delay of negotiations with the $\mathrm{EU}$, due to lack credibility of keeping commitments by the Albanian government. Failure of keeping commitments in relation to the WTO was used as a test for the government and served as an unfavorable precedent for commitments that it would take on within the European integration.

EU, being itself a member of the WTO, with a key position in the organization, considers the seriousness of Albania in implementing WTO commitments a significant test for the country. The direct link between the WTO membership and the relations with the EU in the framework of Stabilization-Association Agreement is emphasized by the fact that the chapters of the Stabilization-Association Agreement dealing with economic and commercial aspects, often make reference to the WTO Agreements.

Albania has drawn upon the assistance of the EU when negotiating in a legal and institutional way (under rules of the WTO) its position with respect to some products.

The EU is currently one of the biggest supporters of the international multilateral trading system represented by the WTO. EU is in fact, the promoter of trade liberalization through the WTO.

Through the WTO, the EU has sought to promote a multilateral framework for trade negotiations, intended to complement, and possibly supplant, bilateral negotiations. However, the stalemate in the latest round of

\footnotetext{
${ }^{13} \mathrm{~A}$ large number of trade-related reforms are being driven by Albania's desire to become more closely integrated into the European Union (EU). The Stabilisation and Association Agreement (SAA) with the EU, which entered into force on 1 April 2009, contains obligations on a range of political, trade, and economic issues. This has complemented implementation of WTO rules, which has already been largely achieved, as the main driving force for institutional and legal reform. However, the Albanian authorities consider approximation to EU rules as a complement to the changes already implemented to comply with WTO provisions, which remain the basis of Albania's trade policy regime.
} 
negotiations and the fact that other trading partners have turned to bilateral agreements have compelled the EU to partly reconsider its long-standing strategy and return to regional and bilateral negotiations. The impasse at the WTO is also a sign that the international trading system has changed dramatically in the last 25 years. The old system, largely dominated by the EU and the US, has evolved into one that is more open and multifaceted, with new actors, essentially transition and developing countries, playing a central role. The liberalization of the international trading system has benefited some developing countries, which have sustained economic growth. (Hofmann \& Gabriele, 2007, p. 4).

Albania's WTO membership should not be considered simply as one more member added to the list of international organizations, but as one of the most successful and difficult memberships, considering its economic and political importance ${ }^{14}$, which has opened the way for Albania to be part of a market economy with clearly defined rules of the game and a referee that can impose sanctions if rules are not respected. Admission to the WTO implies greater protection and guarantee of domestic and foreign investments, a more loyal and liberal market to Albanians and foreigners alike and greater opportunities for the integration of Albania into Euro-Atlantic organizations.

\section{REFERENCE LIST}

Amorim, C. (2003). The Real Cancún. The Wall Street Journal, 25 September.

Cottier, T. Manfred, E. (2011). Governing the World Trade Organization: Past, Present and Beyond Doha. Cambridge: Cambridge University Press.

Ministry of Economy. (2004). Document submitted to the Albanian Department on the relations with the WTO and economic integration. Reforming policies of liberalization in the framework of WTO.

Ministry of Economy. (2005). Document submitted to the Albanian Department on the relations with the WTO and economic integration. On specific commitments on trade in services in the WTO. Prot. No. 1103.

Ministry of Economy. (25/11/2007). Document submitted to the Albanian Department on the relations with the WTO and economic integration. The position of Albania to the WTO negotiations.

Ministry of Economy. (2010). Document submitted to the Albanian Department on the relations with the WTO and economic integration. Notice on the cooperation between Albania and the WTO.

Gallagher, P. (2005). The First Ten Years of the WTO: 1995-2005. Cambridge: Cambridge University Press.

Hofmann, R .Gabriele, T. (2007). The European Union and the WTO Doha Round. Baden: Nomos.

https://www.wto.org/ WT/ALB/51/Add.1:Goods Schedule.04.04.2015

https://www.wto.org/ WT/ALB/51: Report on the working Parties.04.04.2015

https://www.wto.org/WT//ALB/51/Add.2:Services Schedule.06.04.2015

Official Bulletin of the Republic of Albania. (2004), Tirana:QPZ.

Skreli, E., Tanku, A. \& Dyrmishi, A., Gouda.(2005). World Trade Organization and Albanian Business. Tirana: ISHPP.

VanGrasstek, C. (2013). The history and the future of the World Trade Organization. WTO.

World Trade Organization. (2010). From GATT to the WTO: The Multilateral Trading System in the New Millennium. The Hague: Kluwer Law International.

World Trade Organization. (1 July 2011).Factual Presentation/WT/REG226/3.

WTO online information: https://www.wto.org/WT/ALB/40/Rev.2;Changes in Albanian Legislation for Complying with WTO agreements.08.04.2015.

\footnotetext{
${ }^{14}$ Ministry of Economy . (2010). Document submitted to the Albanian Department on the relations with the WTO and economic integration. Notice on the cooperation between Albania and the WTO.
} 